\title{
Regimes in Global Environmental Governance and the Internationalization of the State: The Case of Biodiversity Politics
}

\author{
Ulrich Brand $^{1} \&$ Christoph Görg ${ }^{2}$ \\ ${ }^{1}$ Institute of Political Science, University of Vienna, Universitätsstrasse 7/2, 1010 Vienna, Austria \\ ${ }^{2}$ Helmholtz Centre for Environmental Research, Permoserstr. 15, 04318 Leipzig, Germany \\ Correspondence: Ulrich Brand, Institute of Political Science, University of Vienna, Universitätsstrasse 7/2, 1010 \\ Vienna, Austria. Tel: 43-1-4277-49452. E-mail: ulrich.brand@univie.ac.at
}

Received: January 8, 2013 Accepted: January 23, 2013 Available online: February 23, 2013

doi:10.11114/ijsss.v1i1.75 URL: http://dx.doi.org/10.11114/ijsss.v1i1.75

\begin{abstract}
Scholarly debates on the relative (in-)effectiveness of global environmental governance increasingly focus on problems of cooperation across regime boundaries and on the missing knowledge base for such interlinkages. Global environmental change and related politics are increasingly seen as taking place in a complex field in which several ecological processes are interlinked - e.g. climate change, biodiversity, water, and land-use change - and these processes are deeply interconnected with societal processes, such as food supply and nutrition and the economic and financial crisis. We argue that institutionalist approaches have their merits but they are nevertheless inadequate because they do not seriously address questions concerning the root causes of problems, power, and domination. Furthermore, they do not critically scrutinise how the political institutions of current global environmental governance may in fact support broader socio-economic and political developments. This could effectively undermine the supposed goals of global environmental governance institutions and could seriously threaten other social or ecological processes. Informed by critical research on global environmental governance and adding to this literature insight from critical state theory, we develop an understanding of the internationalized state as well as its role and function in globalized capitalism. We illustrate our argument with recent developments in international biodiversity politics. We show that the predominant forms of politics are not very effective with respect to the ongoing erosion of biodiversity. However, the complicated and conflictive political processes within an apparatus of the internationalised state are mainly in line with hegemonic developments and dominant interest, i.e. the increasing valorization of biodiversity and especially of genetic resources.
\end{abstract}

Keywords: regime interlinkages, global environmental governance failure, political ecology, critical state theory, internationalization of the state, hegemony, biodiversity politics

\section{Introduction}

The failure of the last Conferences of the Parties (COP) to the Framework Convention on Climate Change (FCCC) once again showed that global environmental governance institutions remain quite ineffective in comparison to the strong expectations evoked and the enormous problems they ought to deal with. Another landmark was the $10^{\text {th }}$ COP to the Convention on Biological Diversity in October 2010 in Nagoya where it was acknowledged that the so-called '2010 target' was missed by a long shot even if its ambitions were not very high. (The target, which was formulated in 2002, aimed to significantly reduce the rate of biodiversity loss - not to stop the erosion itself). At the last COP to the CBD in October 2012 in Hyderabad, the lack of effective global environmental governance became evident again.

However, according to some observers, the Nagoya conference was considered a success. One reason for this optimistic assessment is the fact that the so-called Nagoya Protocol on Access and Benefit-Sharing was agreed upon after multi-year negotiations, even if there was a lack of agreement until the very last moment (IISD 2010: 3-8). One function of international environmental agreement becomes visible here: It is not only about reaching self-declared aims and targets (e.g. stopping or reducing environmental degradation) but also about carrying on negotiations and creating global governance rules even if the causes for these rules are arguable.

Taking into account this background, we argue that in order to estimate the outcome of international governance 
and regulation, it is insufficient to look at individual regulatory areas (finance, climate, biodiversity, etc.) in an isolated way or to limit the analysis to one level of decision making, e.g. the international one, thereby neglecting the root causes that deepen the challenges we are confronted with. Societal power relations and strategies of hegemonic actors must be addressed properly and the development path as well as the underlying constellation of actors needs to be taken into account. It is thus necessary to develop a broader understanding of global environmental governance and the reasons for regime ineffectiveness or even regime failure.

In this paper we provide an overview of the debate over regime (in-)effectiveness as discussed in the International Relations literature, especially that of regime theory (see next section). We seek to add to this literature our understanding of the internationalization of the state in an effort to gain even more insight about the ineffectiveness of global environmental governance (third section). In the fourth section, we give a brief historical sketch of a critical interpretation of the development of crisis-driven societal nature relations and link the state-theoretical considerations of the third section with Gramsci's notion of hegemony. ${ }^{1}$ Hegemony is another useful concept to understand the mentioned ineffectiveness. ${ }^{2}$ In the fifth section we illustrate this approach with important developments from the field of international biodiversity policy and politics. The focus of the article is not a discussion of regime theory but it rather aims to develop a critical understanding of the failure of global environmental governance. ${ }^{3}$

The overall argument of the paper is that the existing forms of global environmental governance fail with respect to their stated aims and public crisis consciousness but at the same time they might be functional for dominant socio-economic and political developments. These functionalities, however, could cause serious threats for other social or ecological processes. In order to make this point clear, it 'requires an analysis of both the proximate political factors and deeper social and historical determinants of state action' (Parks/Roberts 2010: 145). ${ }^{4}$

\section{Reasons for Systematic Regime Failure in Global Environmental Governance}

\section{There is a broad literature on Global Environmental Governance in the field of International Relations.}

In particular, research in the context of regime theory has enhanced our knowledge about various environmental problems and efforts to deal with them collectively. We know a lot about how multilateral environmental agreements (MEAs) and regimes are established and how they function, as well as associated opportunities and obstacles for effective performance (Kütting 2000, Young et al. 2008, Breitmeier et al. 2006, Oberthür/Gehring 2006). Some MEAs are effective with respect to their stated aims, while others are less effective (cf. Hovi et al. 2003, Newig/Fritsch 2009).

One recent major advance in institutionalist research on MEAs and in political decision making is the acknowledgement that political institutions or regimes do not exist in a more or less isolated way. The overlapping character of MEAs and their policies - discussed in the scholarly literature under the headings of 'regime interplay' or 'regime interlinkages' - is seen as a crucial problem with respect to their ineffectiveness and it raises the question as to how different regimes can be mutually supportive (Biermann et al. 2009, Oberthür 2009, Chambers 2008). At the same time, Zelli et al. (2010: 1) argue that 'scholarly analysis of horizontal institutional interlinkages still lacks a sound theoretical basis' and Young (2008: 134) states a lack of 'theoretical concerns that can help us to understand the origins and consequences of interplay'. This is exactly what we want to do in the following: to propose concepts and theoretical approaches in order to develop a more sophisticated understanding of global environmental governance and its performance.

On the side of the environmental problems that MEAs should deal with, the complex, coupled socio-ecological systems - e.g. climate change, biodiversity, water, and land-use change - and their underlying driving forces are increasingly taken into account (Carpenter et al. 2006, Millennium Ecosystem Assessment 2005, Rockström et al.

\footnotetext{
${ }^{1}$ We prefer the term 'societal nature relations' (in German: gesellschaftliche Naturverhältnisse, a term used by Marx and developed by Horkheimer and Adorno) compared to 'society-nature-relations' because the former indicates the mediated relation (Vermittlung). Society and nature are co-constitutive and they do not exist independently from each other (Görg 2011).

${ }^{2}$ In this article we do not intend to discuss the rather large field of Gramscian analysis, which does not refer to Poulantzas; this would simply overload the argument.

${ }^{3}$ Fortunately, a reviewer urged us to clarify this point.

${ }^{4}$ However, we go beyond the argument of Parks and Roberts, which is informed by structuralism, constructivism and institutionalism, by also theorising the international terrains of environmental negotiation as state apparatuses. They treat the state still as being national and as a kind of a block-box.
} 
2009, Haberl et al. 2011). Climate change is driven by anthropogenic factors (i.e. connected with the use of fossil fuels, but deepened by other processes like land-use change through deforestation) and thus strongly coupled with societal production and consumption patterns. Furthermore, several biophysical processes are inextricably interlinked with the impacts of climate change, like the erosion of biodiversity, water scarcity in some regions of the world, and increased risks of flooding and sea level rise in others. The vulnerabilities of these regions, however, are produced not only by these 'natural' causes but also by societal factors, e.g. like housing of poor people in vulnerable regions or the undermining of resilient resource management strategies through transnational firms or national development strategies (Adger 2006, Füssel 2007, O’Brien et al. 2007).

Therefore, in addition to the interplay of (international) political institutions, there is, first, a need for an increased understanding of coupled socio-ecological processes; second, an in-depth analysis of the production of social vulnerability; and, third, an estimation of the underlying driving forces. Whereas environmental research replied to the first challenge by creating joint research strategies, the second and third challenges are often neglected or underestimated. In this paper, we focus on the third aspect, i.e. the underlying driving forces, and link this to the question of the relative ineffectiveness of global environmental governance.

Contributions inspired by regime theory still link the ineffectiveness of MEAs to an assumed incoherence of those institutions or regimes. Usually, conflictive norms and rules or weak policy instruments are considered to be the main reasons for ineffectiveness. In recent work, questions of conflicts among actors have been dealt with in order to understand norm collusion. However, conflict is conceptualised as 'positional differences among actors across regimes as articulations of ongoing conflicts (or lack thereof) over broader norms that underpin global environmental governance' (Zelli et al. 2010: 1-2). We will show that conflicts do not only concern relations among actors but that they are mediated through structural factors, like the form of the (national and international) state and its relationships with economy and society.

The precise analysis of policy processes fails to consider questions of the overall transformation of the political and the state as well as questions of political economy and of social actors or forces which exist and act beyond the particular policy process (Newell 2008, Conca et al. 2008, Newell/Paterson 2010, Vogler 2011). One could say, regime theory - like many contributions to the (global) governance debate in general - fails to develop a more sophisticated understanding of the 'subject' of steering, i.e. the state and governance structures and procedures, as well as of the steering 'object', i.e. the complexity of society and societal nature relations. Much work has been done to broaden the perspectives on the constitution, performance, and problems of GEG in a critical way (overviews in Vogler 2011, Conca et al. 2008, Kutting/Lipschutz 2009, Bulkeley 2005). What we wish to add to this literature is a more sophisticated understanding of the state and its internationalisation as an integral part of global environmental governance and its failure.

\section{Critical State Theory and the Internationalisation of the State}

We aim to contribute to the debate on the ineffectiveness of global environmental governance from a political economy and state theoretical perspective, informed by historical-materialist social theory. In order to understand the constitution, functioning, and effectiveness of global environmental governance, we propose in the following that the performance of MEAs and regimes can be better understood when they are conceptualised as part or apparatuses of the multi-scalar internationalised state. Critical state theory understands the state always as a materialised social relation intrinsically related to societal actors and structures - and in so far as part and mode of governance. Moreover, we do not argue that the national scale loses importance. In the actual crisis, we can see that in some respects the contrary is the case. Rather, we argue that political analysis should be open for the concrete structures and performance of the state at different spatial scales (on scale in general, cf. Marston 2000, Brenner 2001, on political ecology, Bulkeley 2005, Rangan/Kull 2009).

We propose here to enhance actor-oriented and institutionalist approaches by inquiring about the role of the state as a social structure and a social relation at different spatial scales. We refer to the literature on historical-materialist state theory and the recent diagnosis of the internationalization of the state, which intends to overcome the narrow binding of the concept of the state to the national scale (Poulantzas 2002 (1978), 2001 (1973), Cox 1987, Jessop 1990, 2007, Hirsch 2005, Sauer/Wöhl 2011, Robinson 2004, Demirović 2011, Bretthauer et al. 2011, Brand/Görg 2008a, 2008b, Brand/Görg/Wissen 2011).

The state is understood as a specific materialised social institution which creates collectively binding decisions. Moreover, it is largely the national state that organizes the specific means by which to exercise a legitimate monopoly over the use of coercion. As such, this is not at odds with approaches to Global Environmental Governance. However, we argue that the separation of the state from society, thus treated as a relatively autonomous entity, means that it is not just an instance to create collectively binding decisions or to solve 
problems but, as a separate entity, it mainly secures and stabilises existing social relations, like the social division of labour (along class, gender, and ethnicity, and also internationally); private ownership of the means of production and the private appropriation of the results of social production; and the relationship among different capital factions and between capitalist and non-capitalist sectors (Poulantzas 2002: 45, 92). Therefore, the institutional materiality of the state - and, we argue, also of the internationalised state - has to be understood against the background of the capitalist mode of production, which also shapes societal nature relations.

The state is institutionally separated but at the same time present in societal relations and those relations are present within the state. This leads to Poulantzas' famous concept of the capitalist state as the material condensation of the relationship of forces between classes and class factions, which always expresses itself within the state as a specific form (2002: 159). As such, the state gives specific constellations of forces and societal orientations certain durability via bureaucratic, legal, financial, epistemic, or discursive means. From this perspective, subaltern forces and actors as well as non-dominant orientations are inscribed into the state, albeit asymmetrically in relation to dominant or even hegemonic forces and orientation. Additionally, Poulantzas argued that the state is not just a passive receiver but it marks out the fields of societal relations like the division of labour and class relations as well as the fields to fight out conflicts (ibid.: 68-9).

Understanding the state as a materially-condensed social relation means that it also constitutes a terrain of contestation which is asymmetrically structured. With respect to societal nature relations, it can be argued that the state first secures the dominant norms of production, distribution, and consumption and, at the same time, emerging socio-ecological conflicts are fought out under conditions that are also created or at least heavily influenced by the state - even if the opposing actors want to distance themselves from the state. It is not by chance that the manifold social conflicts which arise out of the ecological crisis are converted into political ones. The conflicting actors pursue their strategies in alliances with state personnel and under specific rules and conditions, which were previously developed in other struggles where societal actors were asymmetrically involved (like national environmental laws or the MEAs). Therefore, they have no equal access to the state but are confronted with specific selectivities (Jessop 1990: 10, 2007). Political institutions themselves - their modes of recognising problems and demands, their personnel, and their norms and rules - are more open to specific claims than to others, e.g. to the officials of the CBD it seems more appropriate to promote biodiversity politics together with drug and seed companies and not against them. However, those selectivities are not independent from the strategies of the various actors but the latter usually deal with them consciously.

The state as a materialised institution develops contradictions, tensions, and explicit struggles between societal forces - within the power bloc or beyond - and it also takes the form of contradictions between different apparatuses and branches (Poulantzas 2002: 164-5).

Bob Jessop developed the argument that concrete social practices and forces need to be examined in order to understand the performance of state power (Jessop 1990: 364). He proposed that societal practices and forces need to be able to develop and pursue hegemonic projects that can potentially become state projects. Those projects might serve to unify the highly heterogeneous state and its policies.

For our endeavour, this opens a perspective on the dominant or even hegemonic 'post-Fordist' societal nature relations, especially the so far unquestioned valorisation paradigm and ecological modernization (see below), both of which became projects of the internationalised state and might be in severe tension with effective environmental policies.

With respect to international aspects of the state, we emphasise only one aspect of critical state theory in order to enhance a regime theoretical perspective and its problem-solving bias. The internationalised state is crucial for the functioning of the political economy in the sense that it articulates different locations (mainly national societies) through universal measures, standards, and rules, but also times and temporalities that are crucial for economic dynamics.

In order to understand problems of global environmental governance, the state and its politics should be understood together with hegemonic or at least dominant societal relations, especially with political economy (we also include cultural aspects in our notion of political economy; on cultural political economy, cf. Jessop/Sum 2006, Jessop 2010). Therefore, the institutional structures and contents of international, national, and local public policies need to be seen not only with respect to the problems to be dealt with but also in relation to social forces and socio-economic as well as cultural developments. A critical understanding of the state assumes that it is not merely the actions of social actors and the conflicts among them, which are important for state and intergovernmental norm production and policies (cf. Zelli 2010), but that the power relations among the actors are inscribed selectively into the institutional political structures, i.e. the internationalised state and its 
apparatuses.

Before we turn to questions of hegemony in order to understand the political economy of regime ineffectiveness, let us briefly emphasize a final aspect which is important. In contrast to most national states with their means to create certain coherence among different apparatuses, which in Jessop's terms is a 'state project', this is much less the case at the international scale. Sometimes real competition among different institutions can be observed, e.g. among the FAO, WIPO, and the CBD in regulating property rights on genetic resources (Wissen 2009). The reason for that is that at the international level political institutions also condense power relations among states as well as among private actors like corporations or NGOs in different ways. The WTO is another form of power condensation compared to the CBD. We introduced for this fact the concept of 'second order condensations' of societal relationships of forces (Brand et al. 2010, Brand/Görg/Wissen 2011). The relative weight of particular political institutions or apparatuses depends mainly on whether dominant actors, i.e. governments and behind them powerful social interests, are willing and able to convert a specific apparatus into a power centre (e.g. WTO, currently the IMF in Eastern Europe or with respect to global currency policies). But at the international level the mechanisms to create stable asymmetric relations among the apparatuses are still weaker.

\section{The Political Economy of the (In-)Effectiveness of Global Environmental Governance}

We argue that the roots of governance ineffectiveness or failure lie in the very constitution of modern capitalist societies, its embeddedness into North-South relations, and related societal and political forms to appropriate nature. The internationalised state - understood as a multiscalar constellation - is part of more or less hegemonic societal relations, i.e. broadly accepted forms of societal development, production and consumption patterns, and manifold forms of domination. At the same time, the internationalised state is key to managing the tensions and conflicts arising out of the appropriation of nature and the ecological crisis.

We introduce our politico-economic theorizing of the state - political economy is 'political ecology's bread-and-butter' (Mann 2009: 343) - in order to detect the dominant driving forces of societal developments which cause environmental problems and, at the same time, constitute a contingent 'corridor' of policy making. We do not intend to argue in an economistic sense that everything in modern societies can be reduced to the making of profits or to capital accumulation. However, by analysing the ecological crisis and environmental politics, we cannot abstract from capitalist growth imperatives, industrial forms of production and consumption, and certain 'modern' subjectivities when we analyse the ecological crisis and respective policies (Newell 2008, Park et al. 2008, Peet/Watts 2004, Robbins 2004, Forsyth 2009). And we cannot overlook the fact that the state is not a neutral entity above or beside (world-) society but reproduces manifold unsustainable practices. In that sense, the ecological crisis originates in industrial capitalism and especially in the post-War model of growth and development, often called Fordism or peripheral Fordism, respectively (Hirsch 2005, Jessop 2007, Brand/Görg 2008a).

Such a perspective enables us to develop an understanding of the transformation of global (environmental) politics in the last three decades. In other studies we have shown that the current phase of capitalist development since the 1980s is characterised by an intensification of a 'valorisation paradigm', i.e. a growing political economic interest in the appropriation of nature for its marketing. This was not entirely new but gained an enormous dynamic and articulated itself with the beginning of explicit international environmental governance. This is the case for not only water supply, timber production, and genetic resources but also in climate change politics through the invention of the so-called flexible mechanisms (Brand et al. 2010 in general and on genetic resources, on forests Dauvergne/Lister 2010, on carbon dioxide emissions and climate politics Lohmann 2006, Brunnengräber 2006). It is not a mere economic process because the rules for the appropriation of nature have to be set politically, e.g. the protection of intellectual property rights resulting from the use of genetic resources. Therefore, we talk about a 'post-Fordist governance of nature' (Brand/Görg 2008b, Brand et al. 2010). This articulates with hegemonic policy orientations in society reflective of ecological modernization and a liberal environmentalism, i.e. a deeply inscribed faith that the ecological crisis can be dealt with through institutional innovations and adequate political incentives, scientific-technological advances, and a strong growth in resource productivity as well as a 'greening' of production and consumption patterns in general (Hajer 1995, Jänicke 2008, Huber 2008; for the distinction between policy orientations and broader developments cf. Brand 2010).

Despite the broadly acknowledged ecological crisis, even in the actual multiple crisis of the post-Fordist constellation, societal nature relations remain largely unquestioned: The ecological consequences are increasingly politicised but not linked to the dominant mode of production and living (Brand/Wissen 2012). Antonio Gramsci's concept of hegemony applied to predominant societal nature relations helps us to understand this better. Gramsci wanted to understand how, under conditions of the capitalist mode of production, the 
foremost improbable reproduction of antagonist social relations works. And he was keen to understand why and especially how subaltern forces agreed with societal relations in which they are dominated, i.e. what the complex mechanisms of 'the agreement of associated societal wills' are (Gramsci - PN 13: 1536; our translation from the German edition).

Gramsci assumed that the ruling class(es) have to be able to successfully formulate and implement - of course, through contestation and partly trial and error - economic, political, and ideational projects. The state is part of this since it 'armours hegemony with coercion' (PN 6: 783), but hegemony has to be worked out and implemented in civil society (PN 10: 1267).

These projects, if successful - that is the structural feature - have to be reproduced through the myriad of everyday practices, through subjectivities and norms, associations, and political, cultural and economic institutions and might constitute an attractive and dynamic model of capitalist growth (what Gramsci called a historic bloc like Fordism; cf. PN 8: 1045 and the fabulous $22^{\text {nd }} \mathrm{PN}$ on 'Americanism and Fordism'). ${ }^{5}$

With respect to societal nature relations, we can detect that the capital and growth-oriented appropriation of nature with its destructive consequences is hegemonic in the sense that it is one basis for capitalist domination and capital valorisation and subject to constant strategising (and many strategies fail). At the structural level, this creates a mode of living both along and despite class, gender, ethnic, and international lines of division that is reproduced practically every day and is accepted when an alternative beyond the differentiation into more or less 'ecological' life-styles is not visible. In that sense post-Fordist societal nature relations are arguably destructive and at the same time considered to be without alternative - at least for Western societies, but this is also the case for rapidly growing NICs. This has to do with the broad political, economic, and cultural alliances in place; Gramsci spoke of the 'organised consensus' (PN 1: 117-8) and we can detect this within political parties, mass media, business associations, trade unions, and even many liberal environmental groups. Consensus as the relation of the masses to power is not a mere ideational or ideological issue but always has a 'material substance' (Poulantzas 2002: 69), i.e. what we can call an 'imperial mode of living' in Western societies and of the global middle strata in the sense that they rely heavily on resources and cheap labour from their own or from other regions (Wissen/Brand 2012).

Geoff Mann claims that the concept of hegemony in Gramscian terms must 'do more than point out that the ruling bloc is hegemonic and demonstrate the material evidence of its power; it must also explain how and why that hegemony operates in the social life of thought - norms, morality, common sense' and what the role of competing ideas in the context of socio-economic dynamics and politics is about (Mann 2009: 336). We think that the deep embeddedness of mainly destructive societal nature relations offers a way to look at the "how and why'. Competing ideas of a profound socio-ecological transformation are marginalised when they go beyond ecological modernisation and liberal environmentalism at the policy level (cf. Jänicke 2008) or of the growth imperative, valorization, and developmentalism as the broad societal orientation (Brand 2010).

The ecological crisis is broadly acknowledged as a crisis and what makes Gramsci interesting here is his argument that those forces that seek to successfully develop crisis strategies and maintain or become hegemonic - or at least create the image that they can be successful in the future - need an 'ethical' moment of hegemony in this (PN 13: 1569), i.e. a perspective in which political, technical-scientific, economic, and ideational aspects come together and create an attractive and realisable world vision. In some way, ecological modernization, understood as a slight shaping of the dominant Western development path but without questioning it, was such a promise. Actually, it might become a project in the form of a Green New Deal or a Green Economy (Brand 2012).

This does not mean that nothing changes. But the changes take place in the 'corridors' of the valorisation paradigm and ecological modernization. For a realistic analysis of global environmental governance, it is important to detect the dominant or marginalised forms of production and consumption, i.e. asymmetric socio-economic and cultural regimes and their implications for societal nature relations in general and for biodiversity in particular.

For instance, the articulation of an assumed scarcity of fossil resources, on the one hand, and the problem of

\footnotetext{
${ }^{5}$ However, we do not read Gramsci's concept of hegemony in the sense that at one point there is hegemony and at another not. 'Hegemony' is a perspective of consensus-based domination which implies the use of violence as well as phases when hegemonic relations are questioned and restructured through a ‘passive revolution' or 'transformism' (PN 8: 966, Showstack Sassoon 2001). Moreover, such a more procedural perspective helps us to also employ the concept of hegemony for specific societal relations like those related to nature.
} 
climate change and the search for adequate policies, on the other, lead partly to an increase in the production of agrofuels. This is highly compatible with the existing dominant patters of the production of mobility and other energy-intensive forms of living. The institutions of global environmental governance, like the FAO or the FCCC, promote this trend or are, at least, not able to shape it significantly. Moreover and coming back to our argument of the asymmetric relationships among international state apparatuses, political institutions like the European Union with its aim to enhance European 'energy security' and global competitiveness as well as sustainability through its 'Directive 2020' (to achieve 20 per cent of renewable energy until 2020 with a considerable share of agrofuels) are important here.

One aspect becomes clear: Many forms of global environmental governance serve as a political-institutional framework for emerging global markets and articulate local, national, and international forms of domination and not necessarily to deal with internationally agreed upon environmental problems.

As we saw above, the internationalized state constitutes a highly asymmetric and selective terrain to politically deal with manifold societal conflicts and it is not only through such political processes that relationships of various forces and hegemonic developments become stabilized. Today international environmental conflicts take place under conditions of accepted terrains (at the local level it is often very different).

In the next section we intend to make sense of our arguments in the field of international biodiversity politics, which we use more as an illustration than as an extensive case study.

\section{Biodiversity Politics - Conflicting, but Effective for Hegemonic Developments and Dominant Interests}

In this section we aim to illustrate our theoretical considerations against the background of international biodiversity politics. While illustrating our argument, we do not pay much attention to the multi-scalar foundation and effects of developments at the international scale (cf. Brand et al. 2010).

From its beginning in the early 1990s, biodiversity policy was seen as a cross-cutting issue that affects other issues and international negotiation processes. This immediately follows from the very nature of the concept of biodiversity, as it was formulated in the second half of the 1980s, and the specific goals and requirements agreed in the most important MEA of biodiversity policy and politics, the Convention on Biological Diversity (CBD). Following the newly introduced concept of biodiversity (as opposed to long established meanings of biological diversity as species diversity), the issue is not only about species diversity but also about genetic diversity and the diversity of ecosystems and habitats. Moreover, it is precisely the value of biodiversity that makes this new concept so important - but this value encompasses ecological as much as economic and various social ways of valuing nature (cultural, aesthetic, or ethical values; see Wilson 1988, Takacs 1996).

Only in a very narrow sense does the CBD appear to essentially be a nature protection agreement, aiming solely at the conservation of biological diversity. More comprehensively, it can be perceived as offering a new direction for conservation strategies because, compared to earlier agreements, a variety of ecological, social, and economic aspects are taken into account, thus creating one of the most comprehensive environmental agreements of the past century. The CBD identified three equally important objectives: the 'conservation of biological diversity, the sustainable use of its components and the fair and equitable sharing of the benefits arising out of the utilization of genetic resources' (CBD, Art. 1). This third aim was operationalized in October 2010 in the so-called 'Nagoya Protocol' on Access and Benefit Sharing (ABS). Thus, conservation efforts are inextricable linked to questions of use and the sharing of benefits resulting from use. Moreover, compared to other nature conservation agreements, the CBD does not limit itself to restricted access on the subject of protection biodiversity - as expected by a nature protection agreement, but it also acts to 'facilitate access to genetic resources' (CBD, Art. 15.2). In other words, the CBD already lays down in Article 1 that the expected (economic) benefits which are to be shared will be created by guaranteed access to biological diversity, i.e. genetic resources. In general, we can assume that the CBD represents the MEA that encompasses the requirements of sustainability in a very comprehensive manner - but at the same time, this agreement also represents the MEA which reveals in a condensed way the shortcoming of the institutions designed to govern the transformation to sustainable development (see Kütting/Lipschutz 2008, Conca et al. 2008).

In recent years, the ambivalent character of the CBD has become even more evident and creates some challenges for not only policy making but also for social sciences. Three of the most important challenges - i.e. the integration of the aforementioned different aims, national implementation, and its relationship to other agreements - are still far from being resolved within the negotiation process and subsequent policies (Millennium Ecosystem Assessment 2005). Above all, it becomes a matter of concern that the CBD in general expresses a tendency towards a view of biodiversity which is primarily concerned with its economic utility and (exchange) value. Biodiversity markets are growing in a variety of areas, encompassing, for example, offset and 
compensation programs (Madsen et al. 2010) or payments for ecosystem services (Gómez-Baggethun/Ruiz Pérez 2012, McAfee 2012). The finally agreed Nagoya Protocol from 2010 - for which negotiations began more than ten years - is a further milestone in this development.

The CBD creates binding decisions in order to deal with conflicts emerging between local providers of biodiversity and genetic resources in countries of the Global South and research institutes as well as private companies in the Global North about the appropriation of nature (these conflicts are politicised as biopiracy). Under the umbrella of the CBD, these manifold societal conflicts are translated into political, i.e. diplomatic ones. The CBD - like the FAO and other terrains - are accepted to deal with these conflicts and to pursue the interests of different stakeholders. It is not local people and private companies who negotiate but rather 'their' governments in their name. However, there are many examples that illustrate that especially the governments of the so-called provider countries may not have the same interests as local people (cf. case studies in Brand et al. 2010, Burrows 2005). Moreover, in our research during the last 15 years, we have clearly detected that the international state apparatus CBD also performs specific selectivities according to its legal text, its rules, and its functioning, which promote certain interests - especially those of Northern companies and their interest in accessing genetic resources and securing intellectual property rights - and weaken others like those of indigenous peoples, especially when they do not accept the rush for the assumed 'green gold of the genes'.

In its internal provisions, the CBD is shaped by a tendency towards commercialization and creates respective selectivities.

The CBD has even accelerated the commercialization of biological diversity and thus contributes less to its conservation and more to its marketing. At the same time, the constant struggle to convert the CBD into an apparatus that creates legally-binding rules for the appropriation of genetic resources is a step that is further aligned with the Nagoya Protocol.

The CBD remains a contested terrain and the Conferences of the Parties which take place every other year are a clear example to prove this. The concretisation of access rules, the acknowledgement of best practices of biodiversity conservation, the financing of projects, the introduction of new issues like a possible development of a science-policy interface, or the relationship to other terrains are subject to intense debates at the international gatherings. To this extent, the CBD itself, like other international political institutions and networks, developed an important terrain in which relevant actors, especially national governments, can articulate their interests and values. However, the conflicts do not take place on neutral terrain as this terrain is itself in certain ways structured.

By analysing the CBD as an example of the internationalization of the state, it thus becomes obvious that this MEA does not only function as an instrument for solving global environmental problems. In addition, global relations of power and dominance are reproduced. The CBD as an apparatus of the internationalised state is a 'second order condensation' of societal power relations and hegemonic societal orientations because the so-called provider and user countries and various represented societal interests are present in the convention. These interests include those of the so-called life-science industry (using genetic resources for pharmaceuticals or seeds) in accessing genetic resources and securing intellectual property rights, the interests in benefit sharing of the provider countries in the Global South, the interests of conservationist groups, and even those interests of representatives of local farmers and indigenous peoples.

By taking the threefold position of international institutions as regulating authorities, as expressions and stabilizers of global power relations, and as political terrains to deal with conflicts into account, the role of the CBD can be appraised in a more precise manner. The central issue concerns the specific relationship between conservation and use. Very specific ideas and practices exist, which we call different societal nature relations each representing different mixtures of protection and utilization of biodiversity, from indigenous peoples and subsistence farming (in contrast to industrialised agriculture) to nature protection areas and the use of genetic resources by the life-science industry. The real outcome of such international institutions cannot be narrowed down to their effectiveness in terms of environmental protection, but rather how it affects these varying and interdependent societal nature relations and the interests involved.

This very nature of the CBD itself also affects the way the provisions of this MEA overlaps not only with other environmental agreements but also with agricultural and free-trade agreements. Even within international biodiversity politics and policies there exists a broad variety of MEAs, i.e. a complex regime, with very different targets, and those targets are not manageable even within the environmental arena itself. Because of the objectives of the CBD and its subject of regulation, agricultural and trade issues play a role. In this respect, one important experience was that of the United States first refused the signing and subsequent ratification of the 
CBD because of its provisions on intellectual property rights (Wissen 2009). In their view, it conflicts with the provisions of the WTO-TRIPs agreement, which requires introducing some basic IPR protection standards in every WTO member state. Thus, the relations and the conflicts between the CBD and the WTO-TRIPs agreement became one of the contentious issues for international environmental politics during the 1990s. International biodiversity politics creates the legal framework for the appropriation of nature. However, issues of conservation are not absent and not necessarily opposed to the contested institutionalization of the valorization paradigm in the mode of ecological modernization.

The reason for our skeptical judgment of international biodiversity politics is that the challenge of commercialization and valorisation lies not only between international agreements with different goals and subjects, but within these agreements itself. Not even the CBD can escape the valorisation paradigm, which is central to post-Fordist societal nature relations and seems to be intensified during the actual multiple crisis. On the contrary, this paradigm is institutionalised in the CBD, although in a different way to that of the WTO agreements (see above). At the same time, the commercialization of nature is not a linear process but one which is characterised by social struggles and contradictions. This may allow weaker actors (e.g. progressive Southern governments, NGOs, and indigenous peoples) to bring their interests to bear in the negotiations and to be at least partially considered in the compromises. However, how this occurs exactly must be examined as well as how this process allows a degree of maneuverability for certain interests.

To sum up, we sought to emphasize the politico-institutional dimension of hegemony and the importance of the acceptance of the asymmetrical and selective political terrain to create rules and to deal with conflicts. The strategic dimension of formulating politics to exploit the green gold of the genes and to more or less share the gold (here are the main conflicts situated) can be detected as well. The large expectations of the 1990s were reduced; however, they are still present.

We argued that the structural dimension of hegemony has to do with a viable growth model and a passive or even active consensus in everyday lives. Of course, international politics is at first hand detached from everyday life. But when we refer to Gramsci and his argument that socio-economic and political dynamics have to be linked to the ideational, it becomes clear that the ethical-political moment of the hegemony of the valorisation paradigm is its promise to take the problem of biodiversity erosion seriously and its promise that the 'green gold of the genes' for the production of drugs, seeds, and, to a lesser extent, cosmetics will contribute to the solving of severe problems: the ecological crisis, hunger, and illness.

\section{Regime Effectiveness: For What and Whom?}

In this paper we argued that the ineffectiveness or even the failure of regimes needs to be explored from a broad perspective of state transformation and its socio-economic basis. It is not the ineffectiveness or failure of a single institution or a specific arrangement of interconnected regimes that could be resolved by improving institutional or regime coherence. Nor it is the mere acknowledgement and management of conflicting norms or conflicting interests of various actors. This research should consider the questions of for what and for whom regimes are designed and perform and the wider structural framework of state transformation. The 'for what' and 'for whom' questions should not be understood in an functionalist sense but should rather consider the contested character of regime formation, the paths taken and those that are not, the contingencies, and possible failures. If we acknowledge the post-Fordist dynamic of the economic valorisation of nature as an actual dynamic to shape societal nature relations, we can analyse specific regimes and their outcome in more complex ways than just measuring them 'merely' against their stated aims. As we already emphasised, global environmental governance takes place but in distinct ways reflected in the ambitions and objectives of environmentally-concerned politicians, civil society actors, and scholars. More profound proposals and alternatives (Sachs 2007) remain at the edges. Moreover, we tried to present concepts in order to understand the interrelation between political institutional structures, societal structures, ideas or discourses and interests as well as power relations (e.g. with the concept of selectivity). Therefore, the problems or failures of global environmental governance to achieve stated aims of sustainability are not just a question of institutional design but deeply rooted in the structural conditions of capitalist societies. In that sense, we intend to add to the broad range of literature on global environmental politics.

\section{Acknowledgements}

Earlier versions of the paper were presented at the Workshop on 'Issue-Linkages and Regime-Complexes' at the Research and Teaching Centre in International Politics (REPI) at Brussels University in May 2010 and at the Stockholm Conference of the Standing Group on International Relations (SGIR) of the European Consortium of Political Science (ECPR) in September 2010. We are thankful for the important comments we got from the 
participants there as well as from Markus Wissen and the anonymous reviewers of this article. We also thank Benjamin Opratko for research assistance and Wendy Godek for the careful editing of the text.

\section{References}

Adger, W. N. (2006). Vulnerability. Global Environmental Change, 16(3), 268-281. http://dx.doi.org/10.1016/j.gloenvcha.2006.02.006

Biermann, F., Siebenhüner, B., \& Schreyögg, A. (Eds) (2009). International Organizations in Global Environmental Governance. London/New York: Routledge.

Brand, U. (2010). Sustainable development and ecological modernization - the limits to a hegemonic policy knowledge. Innovation: The European Journal of Social Science Research, 23(2), 135-152. http://dx.doi.org/10.1080/13511610.2010.522403

Brand, U. (2012). After Sustainable Development: Green Economy as the Next Oxymoron? In: GAIA Ecological Perspectives for Science and Society, 21(1), 28-32.

Brand, U., \& Görg, C. (2008a). Sustainability and globalisation. A theoretical perspective. In: Conca, K., Park, J., and Finger, M. (Eds), The Crisis of Global Environmental Governance. London/New York: Routledge, 13-33.

Brand, U., \& Görg, C. (2008b). The Clash of Global Regulations. Review of International Political Economy, 15(4), 567-589. http://dx.doi.org/10.1080/09692290802260647

Brand, U., \& Wissen, M. (2012). Global Environmental Politics and the Imperial Mode of Living. Articulations of State-Capital Relations in the Multiple Crisis. Globalizations, 9(4), 547-560. http://dx.doi.org/10.1080/14747731.2012.699928

Brand, U., Görg, C., \& Wissen., M. (2011). Second-order Condensations of Societal Power Relations. The Internationalization of the State from a Neo-Poulantzian Perspective. Antipode, 43(1), 149-175. http://dx.doi.org/10.1111/j.1467-8330.2010.00815.x

Brand, U., Görg, C., Hirsch, J., \& Wissen, M. (2010). Conflicts in Environmental Regulation and the Internationalisation of the State. Contested Terrains, London/New York: Routledge.

Breitmeier, H., Young, O.R., \& Zürn, M. (2006). Analyzing international environmental regimes: from case study to database. Cambridge, MA: The MIT Press.

Brenner, N. (2001). The limits to scale? Methodological reflections on scalar structuration. Progress in Human Geography, 25(4), 591-614. http://dx.doi.org/10.1191/030913201682688959

Bretthauer, L., Gallas, A., Kannankulam, J., \& Stützle, I. (Eds) (2011). Reading Poulantzas: Towards a Contemporary Marxist State Theory. London: Merlin Press.

Brunnengräber, A. (2006). The political economy of the Kyoto protocol. In: Panitch, L., Leys, C. (Eds): Socialist Register 2007: Coming to Terms with Nature. New York: Monthly Review Press, 213-230.

Bulkeley, H. (2005). Reconfiguring environmental governance: Towards a politics of scales and networks. Political Geography, 24(8), 875-902. http://dx.doi.org/10.1016/j.polgeo.2005.07.002

Burrows, B. (Ed) (2005). The Catch. Perspectives in Benefit Sharing. Edmonds: The Edmonds Institute.

Carpenter, S. R., DeFries, R., Dietz, T., Mooney, H. A., Polasky, S., Reid, W., \& Scholes, R. J. (2006). Millennium Ecosystem Assessment: Research Needs. Science, 314, 257-258. http://dx.doi.org/10.1126/science.1131946

Chambers, W. B. (2008). Interlinkages and the Effectiveness of Multilateral Environmental Agreements. Tokyo: United Nations University Press.

Conca, K. (1993). Environmental change and the deep structure of world politics. In: Lipschutz, R.D., Conca, K. (Eds), The State and Social Power in Global Environmental Politics, New York: Columbia University Press: 306-326.

Cox, R. W. (1987). Production, Power and World Order: Social Forces in the Making of History. New York: Columbia University Press.

Dauvergne, P., \& Lister, J. (2010). The Power of Big Box Retail in Global Environmental Governance: Bringing Commodity Chains Back into IR. Millennium, 39(1), 145-160. http://dx.doi.org/10.1177/0305829810371018 
Demirović, A. (2011). Materialist State Theory and the Transnationalization of the Capitalist State. Antipode, 43(1), 38-59. http://dx.doi.org/10.1111/j.1467-8330.2010.00810.x

Forsyth, T. (2003). Critical Political Ecology, London/New York: Routledge.

Füssel, H. M. (2007). Vulnerability: A generally applicable conceptual framework for climate change research. Global Environmental Change, 17(2), 155-167. http://dx.doi.org/10.1016/j.gloenvcha.2006.05.002

Görg, C. (2011). Societal Relationships with Nature: A Dialectical Approach to Environmental Politics. In: Biro, A. (Ed). Critical Ecologies. The Frankfurt School and Contemporary Environmental Crises. Toronto: University of Toronto Press, 43-72.

Görg, C. (2003). Regulation der Naturverhältnisse. Zu einer kritischen Theorie der ökologischen Krise. Münster: Westfälisches Dampfboot.

Görg, C., \& Brand, U. (2006). Contested Regimes in the International Political Economy. Global Environmental Politics, 6(4), 101-123. http://dx.doi.org/10.1162/glep.2006.6.4.101

Gómez-Baggethun, \& E./Ruiz Pérez, M. (2012). Ecosystem services valuation, market-based instruments and the commodification of nature. In: Progress in Physical Geography, 35(5), 613-628.

PN - Gramsci, A. (1991-1999). Gefängnishefte (Prison Notebooks), Hamburg: Argument.

Haberl, H., Fischer-Kowalski, M., Krausmann, F., Martínez-Alier, J., Winiwarter, V. (2011). A Socio-Metabolic Transition towards Sustainability? Challenges for another Great Transformation. Sustainable Development, 19, 1-14. http://dx.doi.org/10.1002/sd.410

Hajer, M. A. (1995). The Politics of Environmental Discourse. Oxford: Claredon Press.

Hirsch, J. (2005). Materialistische Staatstheorie. Transformationsprozesse des kapitalistischen Staatensystems. Hamburg: VSA.

Hovi, J., Sprinz, D. F., \& Underdal, A. (2003). The Oslo-Potsdam Solution to Measuring Regime Effectiveness: Critique, Response, and the Road Ahead. Global Environmental Politics, 3(3), 74-96. http://dx.doi.org/10.1162/152638003322469286

Huber, J. (2008). Pioneer countries and the global diffusion of environmental innovations: Theses from the viewpoint of ecological modernisation theory. Global Environmental Change, 18(3), 360-367. http://dx.doi.org/10.1016/j.gloenvcha.2008.03.004

IISD - International Institute for Sustainable Development. (2010). Earth Negotiations Bulletin 9 (544). COP 10 Final, 1 November 2010. (www.iisd.ca/biodiv/cop10/)

Jänicke, M. (2008). Ecological Modernisation: New Perspectives. Journal of Cleaner Production, 16(5), 557-564. http://dx.doi.org/10.1016/j.jclepro.2007.02.011

Jessop, B. (1990). State theory: Putting capitalist states in their places. Cambridge: Polity Press

Jessop, B. (2007). State Power: A Strategic-relational Approach. Cambridge: Polity.

Jessop, B., \& Sum, N. L. (2006). Towards a Cultural International Political Economy: Poststructuralism and the Italian School. In: de Goede, M. (Ed): International Political Economy and Poststructural Politics. Houndsmill: Palgrave, 157-176.

Kütting, G. (2000). Beyond Regime Theory. Towards Environmental Effectiveness. London/New York: Routledge.

Kütting, G., \& Lipschutz, R. D. (Eds.) (2009). Environmental governance, power and knowledge in a local-global world. London/New York: Routledge.

Lohmann, L. (Ed.) (2006). Carbon Trading. Uppsala: Dag-Hammarskjöld-Foundation.

Madsen, B., Carroll, N., \& Moore Brands, K. (2010). State of Biodiversity Markets Report: Offset and Compensation Programs Worldwide. Washington, DC: Ecosystem Marketplace. (http://ecosystemmarketplace.com/documents/acrobat/sbdmr.pdf)

Mann, G. (2009). Should political ecology be Marxist? A case for Gramsci’s historical materialism. Geoforum, 40(3), 335-344. http://dx.doi.org/10.1016/j.geoforum.2008.12.004

Marston, S. A. (2000). The social construction of scale. Progress in Human Geography, 24(2): 219-242. http://dx.doi.org/10.1191/030913200674086272 
McAfee, K. (2012). The Contradictory Logic of Global Ecosystem Services Markets. In: Development and Change, 43(1). http://dx.doi.org/10.1111/j.1467-7660.2011.01745.x

Millennium Ecosystem Assessment. (2005). Ecosystems and Human Well-being: Synthesis, Washington, DC: Island Press.

Newell, P. (2008). The political economy of global environmental governance. Review of International Studies, 34(2), 507-529.

Newell, P., \& Paterson, M. (2010). Climate Capitalism: Global Warming and the Transformation of the Global Economy. Cambridge: Cambridge UP. http://dx.doi.org/10.1017/CBO9780511761850

Newig, J., \& Fritsch, O. (2009). Environmental Governance: Participatory, Multi-Level - and Effective? Environmental Policy and Governance, 19(3), 197-214. http://dx.doi.org/10.1002/eet.509

Oberthür, S. (2009). Interplay management: enhancing environmental policy integration among international $\begin{array}{llll}\text { institutions. International } & \text { Environmental }\end{array}$ http://dx.doi.org/10.1007/s10784-009-9109-7

Oberthür, S., \& Gehring, T. (Eds) (2006). Institutional Interaction in Global Environmental Governance. Cambridge, MA: The MIT Press.

O’Brien, K., Eriksen, S., Nygaard, L., \& Schjolden, A. (2007). Why different interpretations of vulnerability matter in climate change discourses. Climate Policy, 7(1), 73-88. http://dx.doi.org/10.3763/cpol.2007.0706

Okereke, C., \& Bulkeley, H. (2007). Conceptualising climate change governance beyond the international regime: a review of four theoretical approaches. Working Paper 112, Tyndall Centre for Climate Change Research. (http://www.tyndall.ac.uk/sites/default/files/wp112.pdf)

Park, J., Finger, M., \& Conca, K. (2008). The Death of Rio Environmentalism. In: Conca, K., Finger, M. and Park, J. (Ed.), The Crisis of Global Environmental Governance. London/New York: Routledge, 1-12.

Parks, B. C., \& Roberts, J. T. (2010). Climate Change, Social Theory and Justice. Theory, Culture \& Society, 27(2-3), 134-166. http://dx.doi.org/10.1177/0263276409359018

Peet, R., \& Watts, M. (Eds) (2004). Liberation Ecologies. Environment, Development, Social Movements. London/New York: Routledge.

Poulantzas, N. (2001 [1973]). Die Internationalisierung der kapitalistischen Verhältnisse und der Nationalstaat. In: Hirsch, J., Jessop, B., Poulantzas, N.: Die Zukunft des Staates. Hamburg: VSA, 19-69.

Poulantzas, N. (2002 [1978]). Staatstheorie. Politischer Überbau, Ideologie, sozialistische Demokratie. Hamburg: VSA.

Rangan, H., \& Kull, C. A. (2009). What makes ecology 'political'? Rethinking 'scale' in political ecology. Progress in Human Geography, 33(1), 28-45. http://dx.doi.org/10.1177/0309132508090215

Robbins, P. (2004). Political Ecology. A critical introduction. Hoboken NJ: Wiley-Blackwell.

Robinson, W. I. (2004). A Theory of Global Capitalism: Production, Class, and State in a Transnational World. Baltimore: The Johns Hopkins University Press.

Rockström, J. et al. (2009). Planetary boundaries: exploring the safe operating space for humanity. Nature, 461, 472-475. http://dx.doi.org/10.1038/461472a

Sachs, W. (2007). Fair Future. London: Earthscan.

Showstack Sasson, A. (2001). Globalisation, Hegemony and Passive Revolution. New Political Economy, 6(1), 25-42.

TEEB. (2008). The Economics of Ecosystems and Biodiversity. An Interim Report. Cambridge: European Communities. (http://ec.europa.eu/environment/nature/biodiversity/economics/pdf/teeb_report.pdf)

Takacs, D. (1996). The Idea of Biodiversity: Philosophies of Paradise, Baltimore: John Hopkins University Press.

Vogler, J. (2011). International Relations theory and the environment. In: Kütting, G (Ed). Global Environmental Politics. Concepts, Theories and Case Studies. London/New York: Routledge, 11-26.

Wilson, E. O. (Ed) (1988). Biodiversity. Understanding and protecting our biological resources. Washington, DC: National Academy Press 
Wissen, M. (2009). Contested terrains: Politics of scale, the national state and struggles for the control over nature. Review of International Political Economy, 16(5), 883-906 http://dx.doi.org/10.1080/09692290802529843

Young, O. R. (2008). Deriving Insights from the Case of the WTO and the Cartagena Protocol. In: Young, O.R., Chambers, W.B., Kim, J.A. and ten Have, C. (Eds), Institutional Interplay: Biosafety and Trade. Tokyo: United Nations University Press, 131-158.

Young, O. R., Schroeder, H., \& King, L. A. (Eds) (2008). Institutions and Environmental Change: Principal Findings, Applications, and Research Frontiers. Cambridge, MA: The MIT Press.

Zelli, F., Gupta, A., van Asselt, H., \& Rittberger, V. (2010). Horizontal Institutional Interlinkages: conflicts or collusion? Paper presented at the Workshop on 'Issue-Linkages and Regime-Complexes' at the Research and Teaching Centre in International Politics (REPI), 21-22 May 2010 at Brussels University.

\section{$($ (c) $)$ EY}

This work is licensed under a Creative Commons Attribution 3.0 License. 